\title{
Effect of Zinc and Boron Application on Leaf Area, Photosynthetic Pigments, Stomatal Number and Yield of Cashew
}

\author{
Lakshmipathi" , J.D. Adiga, D. Kalaivanan, B.M. Muralidhara and P. Preethi \\ ICAR-Directorate of Cashew Research, Puttur-574 202, Karnataka, India \\ *Corresponding author
}

\begin{abstract}
A B S T R A C T
\end{abstract}

K e y w o r d s
Cashew, Zinc,
Boron, Chlorophyll,
Carotenoids,
Stomatal count and
yield

An experiment was conducted to study the effect of exogenous application of boron and zinc at different concentrations at three important growth stages (flushing, flowering and fruiting) on leaf area, chlorophyll content, carotenoids, stomatal count and yield of cashew var. Bhaskara. Irrespective of growth stages, foliar application of zinc sulphate $(0.5 \%)+$ borax $(0.1 \%)$ was found to be superior in all the parameters. Out of six treatments, the highest chlorophyll content ( $\mathrm{chl} \mathrm{a,} \mathrm{chl} \mathrm{b}$ and $\mathrm{chl} \mathrm{t}$ ), carotenoids and leaf area were recorded in trees sprayed with zinc sulphate $(0.5 \%)+$ borax $(0.1 \%)$. At flushing stage, spraying with zinc sulphate $(0.5 \%)+$ borax $(0.1 \%)$ resulted in highest stomatal number $(31.05)$ whereas unsprayed (control) trees recorded least stomatal number (12.18). Thus, leaf area, chlorophyll content, carotenoids and stomatal count were increased in trees sprayed with above combination of micronutrients than unsprayed trees. Spraying of zinc sulphate $(0.5 \%)+$ borax $(0.1 \%)$ recorded highest nut yield $(10.80 \mathrm{~kg} /$ tree $)$, whereas unsprayed trees recorded least nut yield $(3.20 \mathrm{~kg} / \mathrm{tree})$. This study demonstrated the potential of zinc sulphate $(0.5 \%)+\operatorname{borax}(0.1 \%)$ in improving various biochemical parameters viz., chlorophyll ' $a$ ', chlorophyll ' $b$ ', total chlorophyll, carotenoids and leaf area in cashew which are important determinants in increasing cashew nut production.

\section{Introduction}

Cashew (Anacardium occidentale L.) belongs to the family Anacardiaceae and is native to Brazil. It was introduced into India by Portuguese travellers in the $16^{\text {th }}$ century for afforestation and soil conservation. Cashew is grown in India, Brazil, Vietnam, Tanzania, Mozambique, Indonesia, Sri Lanka and other tropical Asian and African Countries. India was the first country to exploit the international trade of cashew kernels in the early part of $20^{\text {th }}$ Century (Chavan and Raut,
2013). It earns valuable foreign exchange for the country and is therefore regarded as a "gold mine" (Adiga and Kalaivanan, 2013). Tree nuts are globally consumed for their desirable sensory and nutritional attributes. Among the dry fruits, cashew nuts are very popular due to their characteristic odour and taste. Cashew nuts are a good source of proteins (20\%), carbohydrates (23\%) and fats (45\%) (Bhattacharjee et al., 2003). The global production of cashew is around 37, 13, 467 MT from a total of 60, 37, 313 hectares (FAO, 2014). India is the second largest producer of 
raw cashew nut in the world. India produces about 0.78 million MT of cashew from an area of 1.04 million hectares with a productivity of 0.75 MT/ha (DCCD, 2017).

Pigments in general and chlorophyll in particular are most important for green plants to effectively harvest solar radiation and to convert it into chemical energy. Chlorophyll 'a' plays an important primary role in the photosynthetic process. The status of chlorophyll pigments in the leaf tissue is thus a major determinant of overall photosynthetic efficiency of the plants. The photosynthetic efficiency directly influences the growth, development and yield of the crops. The carotenoids, are organic pigments and act as passive light filters that would reduce light intercepted by chlorophyll (Williams et al., 2003) and thereby provide protection from reactive oxygen species (ROS) (Steyn et al., 2002). Prolonged flowering, poor production of hermaphrodite flowers, low fruit set and premature fruit drop are some major problems plaguing cashew cultivation across the country (Bhat et al., 2010). Cashew productivity can be improved through adoption of appropriate nutrient management regime. Micronutrients deficiency in soil and plants is a worldwide nutritional problem and very severe in many countries (Alloway, 2008; Mousavi et al., 2007). Plants vary in their demand for micronutrients, as these are involved in almost all physiological functions. Some of these elements are redox-active and are cofactors in many enzymes. They have enzyme-activating functions and play structural role in stabilizing proteins (Hänsch and Mendel, 2009).

Numerous nutritional trials, especially those involving the major plant nutrients have been undertaken in India as well as in other tropical countries. However, the influence of micronutrients viz., zinc and boron on cashew productivity has been poorly explored. Foliar application of micronutrients can be resorted for improving growth, photosynthesis, flowering and fruiting in cashew. Hence, it is worthwhile to find out the effect of foliar application of zinc and boron on the concentration of pigments like chlorophyll ' $a$ ' $\&$ ' $b$ ' during the plant growth as it is vital for photosynthesis. Hence, an investigation was taken up to study the influence of foliar application of zinc and boron on leaf area, photosynthetic pigments and stomatal density in cashew.

\section{Materials and Methods}

The experiment was conducted at ICAR Directorate of Cashew Research, Puttur, Karnataka. The experimental site situated in a cashew growing belt, has typical lateritic soils of the west coast, located $87 \mathrm{~m}$ above mean sea level with latitude of $12.77^{\circ} \mathrm{N}$ and longitude of $75.22^{\circ} \mathrm{E}$. The climate is hot and humid throughout the year with an average annual rainfall of $3,500 \mathrm{~mm}$, distributed mainly from June to September. The mean annual temperature was $27.6{ }^{\circ} \mathrm{C}$ and mean maximum and minimum temperature were 36 ${ }^{\circ} \mathrm{C}$ and $20{ }^{\circ} \mathrm{C}$, respectively. The study was carried out on 10 years old plantation (variety Bhaskara) by adopting Randomized Block Design (RBD) with 6 treatments and 4 replications. The details of the treatments were control $\left(\mathrm{T}_{1}\right)$, borax $(0.1 \%)\left(\mathrm{T}_{2}\right)$, borax $(0.2 \%)$ $\left(\mathrm{T}_{3}\right)$, zinc sulphate $(0.5 \%)\left(\mathrm{T}_{4}\right)$, zinc sulphate $(0.5 \%)+$ borax $(0.1 \%)\left(\mathrm{T}_{5}\right)$, zinc sulphate $(0.5 \%)+$ borax $(0.2 \%)\left(\mathrm{T}_{6}\right)$. The micronutrients were sprayed during flushing, flowering and fruiting stage using foot pump paddle sprayer covering the entire canopy. Leaf area was measured using CI-202 Portable Laser Area Meter.

\section{Leaf chlorophyll content}

Chlorophyll 'a', chlorophyll 'b' and total chlorophyll content of the leaves were measured following the method of Arnon 
(1949) and carotenoids by Goodwin's method (1954). One gram leaf sample was taken and chlorophyll was extracted in 80 per cent acetone by grinding in clean mortar. The resulting green liquid was filtered through whatman No. 1 filter paper. The grinding and filtration were repeated 3-4 times for each sample with fresh aliquots of 80 per cent acetone for ensuring the complete extraction of chlorophyll. The final volume was made to $100 \mathrm{ml}$ with 80 per cent acetone. The absorbance of chlorophyll was recorded with spectrophotometer (Spectronic 20) at 645 and $663 \mathrm{~nm}$ against 80 per cent acetone solvent as blank. The entire procedure was carried out in a dark room to avoid the loss of chlorophyll with direct contact of light. Chlorophyll ' $a$ ' and chlorophyll ' $b$ ' contents were calculated. In contrast to the chlorophylls, which absorb light in two regions of the visible spectrum, the carotenoids exhibit intense absorption only in $350-500 \mathrm{~nm}$.

\section{Calculations}

Arnon's equation to convert absorbance measurements to $\mathrm{mg} \mathrm{Chl} \mathrm{g}^{-1}$ leaf tissue is given below.

Chl a $\left(\mathrm{mg} \mathrm{g}^{-1}\right)=[(12.7 \times \mathrm{A} 663)-(2.6 \times$ A645) $] \times \mathrm{ml}$ acetone $/ \mathrm{mg}$ leaf tissue

Chl b $\left(\mathrm{mg} \mathrm{g}^{-1}\right)=[(22.9 \times \mathrm{A} 645)-(4.68 \times$ A663) $] \times \mathrm{ml}$ acetone $/ \mathrm{mg}$ leaf tissue

Total Chl $=\mathrm{Chl} \mathrm{a}+\mathrm{Chl} \mathrm{b}$.

$\mathrm{C}_{\mathrm{x}+\mathrm{c}}=1000 \mathrm{~A} 470-1.90 \mathrm{Chl} \mathrm{a}-63.14 \mathrm{Chl}$ $\mathrm{b} / 214,(\mathrm{x}=$ xanthophylls and $\mathrm{c}=$ carotenes $)$

\section{Stomatal frequency}

Stomata counts were recorded from the mature leaves according to the methods described by Beakbane and Mujumder (1975). The stomatal density was recorded at 10 x 100 magnification field. On each leaf film, three microscopic fields were examined and average was worked out.

\section{Statistical analysis}

Data generated from the experimental plots were analyzed using SAS 9.3 version of the statistical package (SAS Institute Inc, 2011). Analysis of variance (ANOVA) was performed using SAS PROC ANOVA procedure. Means were separated using Fisher's protected least significant difference (LSD) test at a probability level of $\mathrm{p}<0.05$.

\section{Results and Discussion}

\section{Leaf chlorophyll content}

\section{Chlorophyll a}

Foliar application of micronutrients ( $\mathrm{Zn}$ and B) significantly affected chlorophyll content (Table 1). At flushing stage, spraying of $\mathrm{ZnSO}_{4}(0.5 \%)+$ borax $(0.1 \%)$ recorded highest chlorophyll 'a' (1.58) content followed by borax $(0.1 \%)(1.51), \mathrm{ZnSO}_{4}(0.5 \%)(1.44)$, $\mathrm{ZnSO}_{4}(0.5 \%)+\operatorname{borax}(0.2 \%)(1.37)$ and borax $(0.2 \%)(1.01)$, while unsprayed trees (control) recorded least chlorophyll value (0.73).

Application of $\mathrm{ZnSO}_{4}(0.5 \%)+$ borax $(0.1 \%)$ recorded highest chlorophyll 'a' (1.44) content and unsprayed trees (control) recorded least value (0.64) at flowering stage. At fruiting stage also, spraying of $\mathrm{ZnSO}_{4}(0.5 \%)+$ borax $(0.1 \%)$ resulted in highest chlorophyll ' $a$ ' (1.25) while, unsprayed trees (control) recorded least value $(0.37)$. The chlorophyll content increased gradually with leaf expansion in cashew due to spraying of $\mathrm{Zn}$ and B (Balasimha, 1991). Zinc is important for the formation and activity of chlorophyll and in the functioning of several enzymes and the growth hormone (auxin). 


\section{Chlorophyll b}

At flushing stage, spraying of $\mathrm{ZnSO}_{4}(0.5 \%)+$ borax $(0.1 \%)$ resulted in highest Chlorophyll 'b' (0.54) followed by borax $(0.1 \%)(0.50)$, $\mathrm{ZnSO}_{4}(0.5 \%)(0.49), \mathrm{ZnSO}_{4}(0.5 \%)+$ borax $(0.2 \%)$ (0.46), borax (0.2\%) (0.34), while unsprayed trees (control) recorded least value (0.24) (Table 1). At flowering stage, spraying of $\mathrm{ZnSO}_{4}(0.5 \%)+$ borax $(0.1 \%)$ resulted in highest Chlorophyll 'b' (0.52) while unsprayed trees (control) recorded least value (0.21). At fruiting stage, spraying of $\mathrm{ZnSO}_{4}$ $(0.5 \%)+$ borax $(0.1 \%)$ resulted in highest Chlorophyll 'a' (0.97) while, unsprayed trees (control) recorded least value $(0.14)$.

\section{Total chlorophyll}

Effect of foliar application of micronutrients on total chlorophyll of cashew is presented in Table 1. At flushing stage, spraying of $\mathrm{ZnSO}_{4}$ $(0.5 \%)+$ borax $(0.1 \%)$ resulted in highest total chlorophyll (2.12) while, unsprayed trees (control) recorded least value (0.97). At flowering stage, spraying of $\mathrm{ZnSO}_{4}(0.5 \%)+$ borax $(0.1 \%)$ resulted in highest total chlorophyll (2.78) while unsprayed trees (control) recorded least value (1.17). At fruiting stage, spraying of $\mathrm{ZnSO}_{4}(0.5 \%)+$ borax $(0.1 \%)$ resulted in highest total chlorophyll (2.21) while unsprayed trees (control) recorded least value (0.51).The chlorophyll content increased gradually with leaf expansion due to foliar spray of micronutrients (Balasimha, 1991 and Palanisamy et al., 1993).

\section{Chlorophyll a/b}

Chlorophyll $\mathrm{a} / \mathrm{b}$ ratio was not significantly influenced by foliar application of micronutrients at flushing and flowering stage (Table 1). However, at fruiting stage the highest chlorophyll a/b ratio (2.79) was observed in unsprayed trees (control) and lowest chlorophyll $\mathrm{a} / \mathrm{b}$ ratio (1.27) was observed in trees sprayed with $\mathrm{ZnSO}_{4}(0.5 \%)$ + borax $(0.1 \%)$. Micronutrient deficiencies affect carbohydrate pools and photosynthesis. Reduction in chlorophyll content leads to chlorosis in leaves, ultimately affecting the chloroplast system and photosynthesis (Balakrishnan et al., 2000).

\section{Carotenoids}

With respect to different micronutrients, spraying of $\mathrm{ZnSO}_{4}(0.5 \%)+$ borax $(0.1 \%)$ resulted in highest carotenoids (0.54) followed by borax (0.1\%) (0.48), $\mathrm{ZnSO}_{4}(0.5 \%)(0.41)$, $\mathrm{ZnSO}_{4}(0.5 \%)+$ borax $(0.2 \%)(0.32)$, borax $(0.2 \%)(0.29)$, while, it was least in control (0.16) (Table 2). At flowering stage also, spraying of $\mathrm{ZnSO}_{4}(0.5 \%)+$ borax $(0.1 \%)$ recorded highest carotenoids (0.55) whereas unsprayed (control) trees recorded least $(0.12)$ carotenoids. Highest (0.44) and lowest (0.10) carotenoids content was recorded with spraying of $\mathrm{ZnSO}_{4}(0.5 \%)+$ borax $(0.1 \%)$ and control (unsprayed trees) during fruiting stage, respectively.

In the present study chlorophyll ' $a$ ', chlorophyll ' $b$ ', total chlorophyll and carotenoids were significantly improved by the foliar application of $\mathrm{Zn}$ and $\mathrm{B}$. These attributes increased with application of $\mathrm{ZnSO}_{4}$ @ $0.5 \%$. Similar increase in Chl a, b, total and carotenoids was observed by Nahed et al., (2007) in Salvia farinacea by the foliar application of $\mathrm{Zn}$. Results are also in line with Massoud et al., (2005) for pea plants and Farahat et al., (2007) and Wenrong et al., (2008) for Cupressus sempervirens observed that $\mathrm{Zn}$ deficiency resulted decline in leaf $\mathrm{Chl}$ content. Zinc application enhances the rate of photochemical reductions and Chl content in cucumber (Kazemi, 2013). In case of B the highest values for these attributes were recorded in plants sprayed with $0.1 \%$ Borax and decreased at $0.2 \%$ level of Borax. 
Table.1 Effect of micronutrients on chlorophyll content in cashew variety Bhaskara

\begin{tabular}{|c|c|c|c|c|c|c|c|c|c|c|c|c|}
\hline \multirow[t]{2}{*}{ Treatment } & \multicolumn{3}{|c|}{ Chl a mg/g } & \multicolumn{3}{|c|}{ Chl b mg/g } & \multicolumn{3}{|c|}{ Chl t mg/g } & \multicolumn{3}{|c|}{ Chl a/b } \\
\hline & Flush & Flow & Fruit & Flush & Flow & Fruit & Flush & Flow & Fruit & Flush & Flow & Fruit \\
\hline Control & $0.73^{\mathrm{E}}$ & $0.64^{\mathrm{E}}$ & $0.37^{\mathrm{D}}$ & $0.24^{\mathrm{D}}$ & $0.21^{\mathrm{D}}$ & $0.14^{\mathrm{F}}$ & $0.97^{\mathrm{E}}$ & $1.17^{\mathrm{E}}$ & $0.51^{\mathrm{F}}$ & 3.14 & 3.00 & $2.79^{\mathrm{A}}$ \\
\hline Borax $(0.1 \%)$ & $1.51^{\mathrm{B}}$ & $1.41^{\mathrm{AB}}$ & $1.22^{\mathrm{A}}$ & $0.50^{\mathrm{AB}}$ & $0.50^{\mathrm{A}}$ & $0.86^{\mathrm{B}}$ & $2.00^{\mathrm{B}}$ & $2.66^{\mathrm{AB}}$ & $2.08^{\mathrm{B}}$ & 3.06 & 2.83 & $1.38^{\mathrm{DE}}$ \\
\hline Borax $(0.2 \%)$ & $1.01^{\mathrm{D}}$ & $0.92^{\mathrm{D}}$ & $0.61^{\mathrm{C}}$ & $0.34^{\mathrm{C}}$ & $0.32^{\mathrm{C}}$ & $0.29^{\mathrm{E}}$ & $1.35^{\mathrm{D}}$ & $1.69^{\mathrm{D}}$ & $0.90^{\mathrm{E}}$ & 3.06 & 2.87 & $2.16^{\mathrm{BC}}$ \\
\hline $\mathrm{ZnSO}_{4}(0.5 \%)$ & $1.44^{\mathrm{BC}}$ & $1.37^{\mathrm{BC}}$ & $1.20^{\mathrm{A}}$ & $0.49^{\mathrm{AB}}$ & $0.39^{\mathrm{BC}}$ & $0.64^{\mathrm{C}}$ & $1.92^{\mathrm{BC}}$ & $2.59^{\mathrm{B}}$ & $1.81^{\mathrm{C}}$ & 3.04 & 3.60 & $1.89^{\mathrm{CD}}$ \\
\hline $\begin{array}{l}\mathrm{ZnSO}_{4}(0.5 \%)+\text { borax } \\
(0.1 \%)\end{array}$ & $1.58^{\mathrm{A}}$ & $1.44^{\mathrm{A}}$ & $1.25^{\mathrm{A}}$ & $0.54^{\mathrm{A}}$ & $0.52^{\mathrm{A}}$ & $0.97^{\mathrm{A}}$ & $2.12^{\mathrm{A}}$ & $2.78^{\mathrm{A}}$ & $2.21^{\mathrm{A}}$ & 2.97 & 2.76 & $1.27^{\mathrm{E}}$ \\
\hline $\begin{array}{l}\mathrm{ZnSO}_{4}(0.5 \%)+\text { borax } \\
(0.2 \%)\end{array}$ & $1.37^{\mathrm{C}}$ & $1.32^{\mathrm{C}}$ & $1.04^{\mathrm{B}}$ & $0.46^{\mathrm{B}}$ & $0.41^{\mathrm{B}}$ & $0.39^{\mathrm{D}}$ & $1.83^{\mathrm{C}}$ & $2.44^{\mathrm{C}}$ & $1.43^{\mathrm{D}}$ & 2.98 & 3.20 & $2.69^{\mathrm{AB}}$ \\
\hline General mean & 1.27 & 1.18 & 0.95 & 0.43 & 0.39 & 0.55 & 1.70 & 2.22 & 1.49 & 3.04 & 3.04 & 2.03 \\
\hline SE(d) & 0.03 & 0.03 & 0.03 & 0.03 & 0.03 & 0.03 & 0.04 & 0.07 & 0.04 & 0.23 & 0.26 & 0.25 \\
\hline $\operatorname{LSD}(5 \%)$ & 0.07 & 0.07 & 0.08 & 0.07 & 0.07 & 0.07 & 0.09 & 0.15 & 0.10 & NS & NS & 0.54 \\
\hline
\end{tabular}

Table.2 Effect of micronutrients on leaf area, carotenoids and stomatal numbers in cashew

\begin{tabular}{|c|c|c|c|c|c|c|c|c|c|}
\hline \multirow[t]{2}{*}{ Treatment } & \multicolumn{3}{|c|}{ Leaf area $\left(\mathrm{cm}^{2}\right)$} & \multicolumn{3}{|c|}{ Carotenoids mg/g } & \multicolumn{3}{|c|}{ Stomatal number } \\
\hline & Flush & Flow & Fruit & Flush & Flow & Fruit & Flush & Flow & Fruit \\
\hline Control & $68.83^{\mathrm{F}}$ & $66.78^{\mathrm{F}}$ & $64.58^{\mathrm{F}}$ & $0.16^{\mathrm{D}}$ & $0.12^{\mathrm{E}}$ & $0.10^{\mathrm{E}}$ & $17.80^{\mathrm{D}}$ & $15.50^{\mathrm{E}}$ & $12.10^{\mathrm{E}}$ \\
\hline Borax $(0.1 \%)$ & $144.43^{\mathrm{B}}$ & $144.00^{\mathrm{B}}$ & $139.78^{\mathrm{B}}$ & $0.48^{\mathrm{A}}$ & $0.43^{\mathrm{B}}$ & $0.37^{\mathrm{B}}$ & $25.78^{\mathrm{B}}$ & $25.78^{\mathrm{B}}$ & $21.08^{\mathrm{B}}$ \\
\hline Borax $(0.2 \%)$ & $98.45^{\mathrm{E}}$ & $97.38^{\mathrm{E}}$ & $96.05^{\mathrm{E}}$ & $0.29^{C}$ & $0.27^{\mathrm{D}}$ & $0.20^{\mathrm{D}}$ & $19.78^{\mathrm{CD}}$ & $18.53^{\mathrm{D}}$ & $14.25^{\mathrm{DE}}$ \\
\hline $\mathrm{ZnSO}_{4}(0.5 \%)$ & $129.85^{\mathrm{C}}$ & $127.95^{\mathrm{C}}$ & $125.13^{\mathrm{C}}$ & $0.41^{\mathrm{B}}$ & $0.35^{\mathrm{C}}$ & $0.34^{\mathrm{B}}$ & $22.10^{\mathrm{C}}$ & $20.70^{\mathrm{C}}$ & $17.50^{\mathrm{C}}$ \\
\hline $\mathrm{ZnSO}_{4}(0.5 \%)+\operatorname{borax}(0.1 \%)$ & $156.10^{\mathrm{A}}$ & $153.83^{\mathrm{A}}$ & $151.65^{\mathrm{A}}$ & $0.54^{\mathrm{A}}$ & $0.55^{\mathrm{A}}$ & $0.44^{\mathrm{A}}$ & $31.05^{\mathrm{A}}$ & $28.33^{\mathrm{A}}$ & $24.75^{\mathrm{A}}$ \\
\hline $\mathrm{ZnSO}_{4}(0.5 \%)+\operatorname{borax}(0.2 \%)$ & $106.62^{\mathrm{D}}$ & $106.35^{\mathrm{D}}$ & $104.53^{\mathrm{D}}$ & $0.32^{\mathrm{C}}$ & $0.26^{\mathrm{D}}$ & $0.26^{\mathrm{C}}$ & $20.77^{\mathrm{C}}$ & $18.88^{\mathrm{CD}}$ & $16.50^{\mathrm{CD}}$ \\
\hline General mean & 117.38 & 116.05 & 113.62 & 0.37 & 0.33 & 0.28 & 22.88 & 21.28 & 17.70 \\
\hline $\mathrm{SE}(\mathrm{d})$ & 2.55 & 1.87 & 2.23 & 0.03 & 0.02 & 0.02 & 1.35 & 0.99 & 1.40 \\
\hline $\operatorname{LSD}(5 \%)$ & 5.43 & 3.98 & 4.75 & 0.06 & 0.06 & 0.04 & 2.89 & 2.12 & 2.99 \\
\hline
\end{tabular}


Table.3 Effect of micronutrients on nut yield of cashew (Anacardium occidentale L.) var. Bhaskara

\begin{tabular}{|l|c|}
\hline Treatment & Nut yield kg/tree \\
\hline Control & $3.20^{\mathrm{F}}$ \\
\hline Borax $(0.1 \%)$ & $9.60^{\mathrm{B}}$ \\
\hline Borax $(\mathbf{0 . 2} \%)$ & $6.40^{\mathrm{E}}$ \\
\hline $\mathrm{ZnSO}_{4}(\mathbf{0 . 5} \%)$ & $8.20^{\mathrm{C}}$ \\
\hline $\mathrm{ZnSO}_{4}(\mathbf{0 . 5} \%)+\operatorname{borax}(\mathbf{0 . 1} \%)$ & $10.80^{\mathrm{A}}$ \\
\hline $\mathrm{ZnSO}_{4}(\mathbf{0 . 5} \%)+\operatorname{borax}(\mathbf{0 . 2} \%)$ & $7.60^{\mathrm{D}}$ \\
\hline General Mean & 7.63 \\
\hline SE(d) & 0.072 \\
\hline LSD at 5\% & 0.154 \\
\hline
\end{tabular}

The reduction in chlorophyll and carotenoids at higher level of B may be due to its toxic effect or production of reactive oxygen species (ROS) which hinders the biosynthesis of these pigments or it binds $\mathrm{SH}$ group chloroplast and destroys its structure and function and decreases chlorophyll biosynthesis (Hou et al., 2007). Higher concentrations of $\mathrm{B}$ resulted in a pronounced reduction in the photo-reduction activities of PSII. The physiological analysis of photosynthetic pigments like $\mathrm{Chl} a, b$, total and carotenoids were significantly increased by application of micronutrients due to enhancement in secondary metabolites (Shitole and Dhumal, 2012).

\section{Leaf area}

Plant leaf area is an important determinant of light interception and consequently of transpiration, photosynthesis as well as plant productivity. Significant difference was observed in leaf area with respect to foliar application of micronutrients in cashew (Table 2). Among the treatments, spraying of $\mathrm{ZnSO}_{4}(0.5 \%)+$ borax $(0.1 \%)$ at flushing stage resulted in highest leaf area $(156.10$ $\left.\mathrm{cm}^{2}\right)$ followed by borax $(0.1 \%)\left(144.43 \mathrm{~cm}^{2}\right)$, $\mathrm{ZnSO}_{4}(0.5 \%)\left(129.85 \mathrm{~cm}^{2}\right), \mathrm{ZnSO}_{4}(0.5 \%)+$ borax $(0.2 \%)\left(106.62 \mathrm{~cm}^{2}\right)$, borax $(0.2 \%)$ $\left(98.45 \mathrm{~cm}^{2}\right)$ and control $\left(68.83 \mathrm{~cm}^{2}\right)$. At flowering stage, the leaf area was found to be maximum $\left(153.83 \mathrm{~cm}^{2}\right)$ in $\mathrm{ZnSO}_{4}(0.5 \%)+$ borax $(0.1 \%)$ spray and minimum $\left(66.78 \mathrm{~cm}^{2}\right)$ in unsprayed (control) trees. Foliar application of $\mathrm{ZnSO}_{4}(0.5 \%)+$ borax $(0.1 \%)$ during fruiting stage recorded significantly higher leaf area $\left(151.65 \mathrm{~cm}^{2}\right)$ over other treatments. Significant increase in leaf area could be due to increased metabolic activity by increased supply of nutrients (Goudriaan and Van Laar, 1994; Wahdan et al., 2011). Role of micro nutrients in increasing leaf area can be ascribed to their influence on cell division and cell elongation. Higher leaf area values recorded with $\mathrm{ZnSO}_{4}(0.5 \%)+$ borax $(0.1 \%)$ may also be due to increased concentration of photosynthates in the shoot (Nunez et al., 1998; Zoffoli et al., 2009 and Zahoor et al., 2011) as reported in grape (Vitis vinifera $\mathrm{L}$.).

\section{Stomatal number}

The stomata are apertures in the epidermis, each bounded by two guard cells. Their main function is to allow gases such as carbon dioxide, water vapors and oxygen to move rapidly into and out of the leaf. Stomatal density can vary within leaves, plants, and individuals of a single species. Data on stomatal number as influenced by foliar application of micronutrients is presented in 
Table 2. The maximum number of stomata under the leaves was recorded with spraying of $\mathrm{ZnSO}_{4}(0.5 \%)+$ borax $(0.1 \%)$ (31.05) followed by borax (0.1\%) (25.78) and $\mathrm{ZnSO}_{4}$ $(0.5 \%)$ (22.10). Minimum number of stomata was found in control (17.80). The remaining treatments had intermediate number of stomata. Application of $\mathrm{ZnSO}_{4}(0.5 \%)+$ borax $(0.1 \%)$ at flowering stage recorded the highest stomatal number (28.33) and control recorded the least (15.50) number of stomata. At flowering stage, spraying of $\mathrm{ZnSO}_{4}(0.5 \%)$ + borax $(0.1 \%)$ resulted in highest stomatal number (24.75) whereas unsprayed (control) trees recorded least (12.10) stomatal number. This was due to the fact that nutrients are readily absorbed by leaves and translocated within the plant when they are dissolved in water and sprayed on them resulting in higher leaf area and stomatal number. Higher leaf area as a result of micronutrient spray might have been the chief cause for increased number of stomata in micronutrient sprayed trees (Farshid Aref, 2011).

\section{Nut yield}

Foliar application of micronutrients played a significant role in increasing nut yield of cashew. The highest nut yield $(10.80 \mathrm{~kg} / \mathrm{tree})$ was recorded with spraying of zinc sulphate $(0.5 \%)+$ borax $(0.1 \%)$ which was significantly superior over other treatments (Table 3). The lowest yield of $3.2 \mathrm{~kg} /$ tree was recorded with control (unsprayed trees). Nut yield depends on the synthesis and accumulation of photosynthates and their distribution among various plant parts. The synthesis, accumulation and translocation of photosynthates depend upon efficient photosynthetic structure as well as the extent of translocation into sink and also on plant growth and development during early stages of crop growth. This may be attributed to fulfillment of the demand of the crop by higher assimilation and translocation of photosynthates from source (leaves) to sink (nut), through supply of required nutrients by foliar spray of micronutrients. These results are in corroboration with the findings of Tariq et al., (2014). Razzaq et al., (2013) reported that foliar application of $\mathrm{Zn}$ enhanced productivity with better fruit quality in 'Kinnow' mandarin because $\mathrm{Zn}$ plays an active role in biosynthesis of auxins (Alloway, 2008). Boron application increases fruit set and yield in several fruit and nut trees, including almond, Italian prune, olive, and sour cherry (Slavko et al., 2001). Increased stomatal number due to application of zinc sulphate $(0.5 \%)+$ borax $(0.1 \%)$ increases inflow of carbon dioxide into the mesophyll tissue resulting more photosynthates, latter partitioned towards nut resulted in more nut yield (Aliyu et al., 2011).

In the present study, foliar application of zinc sulphate@ $0.5 \%$ and borax @ 0.1\% was found to improve the leaf area, photosynthetic pigments (chlorophyll a, chlorophyll b, total chlorophyll and carotenoids) and stomatal density in cashew and also effective in enhancing the nut yield of cashew.

\section{References}

Adiga, J.D. and Kalaivanan, D. 2013. Influence of dwarf rootstocks on growth and vigour of popular Cashew cultivars. Journal of Plantation Crops 41(3): 428432.

Aliyu, O.M., Adeigbe, O.O. and Awopetu, J.A. 2011. Foliar application of the exogenous plant hormones at preblooming stage improves flowering and fruiting in cashew (Anacardium occidentale L.). Journal of CropScience and Biotechnology 14: 143-150.

Alloway, B.J. 2008. Zinc in soils and crop nutrition. Second edition, published by IZA and IFA, p. 1-39.

Aly, E.Z. and Isamail, H.A. 2000. Effect of 
preharvest $\mathrm{GA}_{3}, \mathrm{CaCl}_{2}$ and boron treatments on quality and enzymatic browning in Balady guava fruits. Annu. Agri. Sci. 38(2):1101-1108.

Arnon, D.I. 1949. Copper enzymes in isolation chloroplasts polyphenol oxidase in Beta vulgaris. Plant physiology 24: 1-15.

Arora, J.S. and J.R. Singh. 1970. Some effects of foliar application of $\mathrm{ZnSO}_{4}$ on growth, yield and fruit quality of Psidium guajava L. J. Jap. Soc. Hort. Sci. 39:207-211.

Awasthi, R.P., Tripathi, B.R. and Singh, A. 1975. Effect of foliar sprays of Zinc on fruit drop and quality of litchi. Punjab Hort. J. 15:14-16.

Babu, N. and Singh, A.R. 2001. Effect of foliar application of boron, Zinc and copper on chemical characteristics of litchi fruits. Bioved. 12(1/2):45-48.

Balakrishnan, K., Rajendran, R. and Kulandaivelu, G. 2000. Differential responses to iron, magnesium and zinc deficiency on pigment composition, nutrient content and photosynthetic activity in tropical fruit crops. Photosynthetica. 38:477-479.

Balasimha, D. 1991. Photosynthetic characteristics of cashew trees. Photosyntica 25 (3): 419-423.

Beakbane, A.B. and Mujumder, P.K. 1975. A relationship between stomatal density and growth potential in apple rootstocks. Journal of Horticultural Sciences 50: 285-289.

Bhat, M.G., Nagaraja, K.V. and Rupa, T.R. 2010. Cashew Research in India. Journal of Horticultural Sciences 5: 116.

Bhattacharjee, P., Singhal, R., Gholap, A., Variyar, P. and Bongirwar, D. 2003. Hydrocarbons as marker compounds for irradiated cashew nut. Food Chemistry 80: $151-157$.

Cakmak, I. 2008. Enrichment or cereal grains with zinc: agronomic or genetic biofortification. Pl. \& Soil. 302:1-17.

Chavan, S.P. and Raut, U.A. 2013. Genetic diversity based on morphological and molecular markers in cashew (Anacardium occidentale L.) genotypes. Vegetos 26 (2): 255-263.

Data/Content Files/ContentFile20170627102737AM.pdf

DCCD 2017.. Area and production of cashew in 2016-17. http://dccd.gov.in /WriteRead

Dutta, P. 2004. Effect of foliar application on panicle growth, fruit retention and physico-chemical characters of mango cv. Himsagar. Indian J. Hort. 61 (30):265-266.

Dutta, P., Banik, A. and Dhua, R.S.2000. Effect of different concentrations of boron on fruit set, fruit retention and fruit quality of litchi cv. Bombai. Indian Hort. 57 (4): 287290.

Edward Raja, M. 2009. Importance of micronutrients in the changing horticultural scenario in India. J. Hort. Sci. 4 (1): 1-27.

Edward Raja, M. and Anilkumar, S.C. 2005. Boron deficiencies in mango (Mangifera indica L.) cause delineation study in acidic soils of Maharashtra, India. Soil Sci. \& Pl. Nutr. 51:313-322.

FAO 2014. FAO Statistical Yearbook-2014. Food and Agriculture Organization, Rome, Italy.

Farahat, M.M., S. Ibrahim, S. Lobna, Taha and E.M. Fatma ElQuesni. 2007. Response of vegetative growth and some chemical constituents of Cupressus sempervirens $\mathrm{L}$. to foliar application of ascorbic acid and zinc at Nubaria. World J. Agric. Sci., 3: 45-56.

Farshid Aref, 2011. Influence of zinc and boron nutrition on copper, manganese and iron concentration in the maize leaf. Australian J. Basic and Applied Sci., 
5(7): 52

Goodwin, T.W. 1954. In. Handbook of Plant Analysis. Peach, K. and Tracey, M.V. (Eds). Springer. Berlin. pp. 272-311.

Goudriaan, J. and Van Laar, H. H. 1994. Modelling potential crop growth processes. Kluwer Academic Publishers, Dordrecht, The Netherlands.

Hänsch, R. and R.R. Mendel. 2009. Physiological functions of mineral micronutrients $(\mathrm{Cu}, \mathrm{Zn}, \mathrm{Mn}, \mathrm{Fe}, \mathrm{Ni}, \mathrm{Mo}$, B, Cl). Curr. Opin. Plant Biol., 12: 259266.

Hou, W.H., G.L. Song, Q.H. Wang and C.C. Chang. 2007. Effects of copper and cadmium on heavy metal polluted water body restoration by duckweed (Lemna minor). Plant Physiol. Biochem., 45: 269.

Kachave, D.B. and Bhosale, A.M. 2007. Effect of PGR and micronutrients on fruiting and yield of kagzi lime fruits. Asia J. Hort. 2(2):75-79.

Kazemi, M. 2013. Foliar application of iron and zinc on growth and productivity of cucumber. Bull. Environ. Pharmacol. Life Sci., 2: 11-14.

Mousavi, S.R., Galavi, M and G. Ahmadvand. 2007. Effect of zinc and manganese foliar application on yield, quality and enrichment on potato (Solanum tuberosum L.). Asian J. Plant. Sci., 6: 1256-1260.

Nunez, M., Musa, J.L., Alfonso, J.L. and Coll, F. 1998.The influence of two new Cuban Bioregulators on plant yield of onion (Allium cepa) cv. 'Red Creole'. Cultivas Trop. 19:21-24.

Palanisamy, K. and Yadukumar, N. and E.V.V. Bhaskara Rao.1993. Physiological characteristics of cashew in intercropped system. Plant Physiology and Biochemistry 20 (2): 990-101.

Panwar, R.D., Saini, R.S., Kaushik, R.A. and Yamadagni, R. 1995. Effect of micronutrients on fruit retention, yield and quality of aonla cv.Banarasi under rainfed condition. Haryana J. Hort. Sci. 22 (1-2):250-251.

Rajput, C.B.S. and Chand, S. 1976. Effect of boron and zinc on physico-chemical composition of guava fruits. J.National Agri.Soc.Ceylon.13:49-53.

Razzaq, K.A., S. Khan, A.U. Malik, M. Shahid and S. Ullah. 2013. Foliar application of zinc influences the leaf mineral status, vegetative and reproductive growth, and yield and fruit quality of 'KINNOW' mandarin. $J$. Plant. Nutr., 36: 1479-1495.

Rerkasem, B., Lordkaew, S. and Dell, B. 1996. Boron requirement for reproductive development in wheat. Proc. XIII Int'l. Pl. Nutr. Colloq. Tokyo.

SAS Institute Inc. 2011. SAS® 9.3 Macro Language: Reference. Cary, NC, USA.

Sharma, R.K., Kumar, R. and Thakur, S.1991. Effect of foliar feeding of Potassium, Calcium and Zinc on yield and quality of Guava. Indian J. Hort. 48(4):312314.

Shitole, S.M. and K.N. Dhumal. 2012. Influence of foliar applications of micronutrients on photosynthetic pigments and organic constituents of medicinal plant Cassia angustifolia Vahl. Ann. Biol. Res., 3: 520-526

Singh, P.C., Gangwar, R.S. and Singh, V.K. 2012. Effect of micronutrients spray on fruit drop, fruit quality and yield of Aonla cv.Banarasi. Hort. Flora Res. Spectrum.1 (1):73-76.

Singh, R.R and Rajput, C.B.S. 1977. Effect of various concentrations of Zinc on vegetative growth characters, flowering, fruiting and physico-chemical composition of fruits in mango (Mangifera indica L.) cultivar chausa. Haryana J. Hort. Sci.6:10-14.

Slavko, P., P.H. Brown, J.H. Connell, A.M.S. 
Nyomora, C. Dordas and H. Hu. 2001. Foliar boron application improves flower fertility and fruit set of olive. Hort. Sci., 36: 714-716.

Steyn, W.J, Wand, S.J.E., Holcroft, D.M. and Jacobs, G. 2002. Anthocyanins in vegetative tissues: a proposed unified function in photo protection. New Physiologist 155: 349- 361.

Swietlik, D. 1999. Zinc nutrition in horticultural crops. Hort. Reviews. 23: 109-180. John Wiley\& Sons, Inc., New York.

Tariq, A., Anjum, S.A., Randhawa, M. A., Ullah, E., Naeem, M., Qamar, R., Ashraf, U. and Nadeem, M., 2014, Influence of Zinc Nutrition on Growth and Yield Behaviour of Maize (Zea mays L.) Hybrids. American J. Pl. Sci., 5: 2646-2654.

Wahdan, M. T., Habib, S. E., Bassal, M. A. and Qaoud, E. M. 2011. Effect of some chemicals on growth, fruiting, yield and fruit quality of "SuccaryAbiad" mango cv. Journal of American Science. 7(2): 651-658.

Wenrong, C., Y. Xiaeo, H. Zhenli, F. Ying and H. Fenghog. 2008. Differential change in photosynthetic capacity, chlorophyll fluorescence and chloroplast ultra-structure between $\mathrm{Zn}$ efficient and Zn-inefficient rice genotypes (Oryza sativa) under low zinc stress. J. Physiol. Plant., 132: 89101.

Williams, E.L., Hovenden, M.J. and Close, D.C. 2003. Strategies of light energy utilization, dissipation and attenuation in six co-occurring alpine health species in Tasmania. Functional Plant Biology 30: 1205-1218.

Zahoor, A. B., Rizwan, R. and Javid, A.B. 2011. Effect of plant growth regulators on leaf number, leaf area and leaf dry matter in grape. Not. Sci. Biol. 3 (1):8790.

Zoffoli, J.P., Latorre, B. A. and Naranjo, P. 2009. Pre-harvest application of growth regulators and their effect on postharvest quality of table grapes during cold storage. Post-Harvest Bio. Tech. 51:183-192.

\section{How to cite this article:}

Lakshmipathi, J.D. Adiga, D. Kalaivanan, B.M. Muralidhara and Preethi, P. 2018. Effect of Zinc and Boron Application on Leaf Area, Photosynthetic Pigments, Stomatal Number and Yield of Cashew. Int.J.Curr.Microbiol.App.Sci. 7(01): 1786-1795. doi: https://doi.org/10.20546/ijcmas.2018.701.216 